\title{
Comparison of Laser Desorption and Matrix-Assisted Laser Desorption/Ionization for Ruthenium and Osmium Trisbipyridine Complexes Using Fourier Transform Mass Spectrometry
}

\author{
Jason E. Ham and Bill Durham \\ Department of Chemistry and Biochemistry, University of Arkansas, Fayetteville, Arkansas, USA \\ Jill R. Scott \\ Idaho National Engineering and Environmental Laboratory, Idaho Falls, Idaho, USA
}

\begin{abstract}
Metal-bipyridine complexes are a vehicle for developing approaches for studying the fluorescence of gas-phase ions; however, conclusions regarding fluorescence behavior depend on explicitly identifying the ionic species in the gas phase. $\left[\mathrm{Ru}(\mathrm{bpy})_{3}\right] X_{2}$ and $\left[\mathrm{Os}\left(\mathrm{bpy} \mathrm{y}_{3}\right)\right] X_{2}$, (where bpy $=2,2$-bipyridine and $X=\mathrm{Cl}$ or $\mathrm{PF}_{6}$ ), were studied using direct laser desorption (LD) and matrix-assisted laser desorption/ionization (MALDI) using Fourier transform mass spectrometry (FTMS). LD spectra of the $\mathrm{PF}_{6}$ salt of the $\mathrm{Ru}$ and Os complexes reveal counterion attachment, fluoride transfer, and significant losses of $\mathrm{H}$ for a number of peaks. LD of the chloride salt complexes produced loss of a single bpy ligand, chloride attachment, and losses of $\mathrm{H}$. Spectra of $\left[\mathrm{Ru}\left(\mathrm{bpy}_{3}\right] \mathrm{X}_{2}\right.$ where $\mathrm{X}=\mathrm{BF}_{4}^{-}, \mathrm{CF}_{3} \mathrm{SO}_{3}^{-}$, and $\mathrm{SCN}^{-}$were also collected using LD and compared with the spectra for $\mathrm{Cl}_{2}$ and $\mathrm{PF}_{6}$ salts. Regardless of counterion, loss of $\mathrm{H}$ is observed in LD spectra. MALDI spectra of the trisbipyridyl complexes using 2,5-dihydroxybenzoic acid (DHB) and sinapinic acid (SA) as the matrix were also obtained. The spectra using SA as matrix show intact molecular ion peaks with very little fragmentation and no counterion attachment. Unlike SA, the spectra obtained using DHB look similar to LD spectra with significant losses of $\mathrm{H}$. Our results are consistent with a reaction scheme for hydrogen loss from a carbon that also involves breaking of the metal-nitrogen bond, rotation of a pyridine ring, and re-formation of an ortho-metallated complex by a metal- $C$ bond. These results demonstrate the importance of ion generation method and the utilization of FTMS for correct characterization of metal poly(pyridyl) complexes. (J Am Soc Mass Spectrom 2003, 14, 393-400) (c) 2003 American Society for Mass Spectrometry
\end{abstract}

I nterest in metal-bipyridine complexes arise from their potential use in a variety of applications such as artificial photosynthesis [1], photocatalysis [2], and light-activated pharmaceuticals [3,4]. Additionally, they have successfully been used in solution as light switches to study electron-transfer reactions [5-7]. Our interest has been related to studying optical properties of ions trapped in a Fourier transform mass spectrometer (FTMS) [8]. Based on solution evidence, ruthenium trisbipyridine would be a good candidate for these studies because of the structural stability, high quantum efficiencies, and long lifetimes for fluorescence [1]. Mass spectrometry (MS) investigations of metal-bipyridines have predominantly been performed using fast atom

Published online March 18, 2003

Address reprint requests to Dr. J. R. Scott, MS 2208, INEEL, 2525 N. Fremont Ave., Idaho, ID 83415, USA. E-mail: scotjr@inel.gov bombardment (FAB) [9-13]. Very few studies have used either laser desorption (LD) [14, 15] or matrixassisted laser desorption/ionization (MALDI) [16] techniques.

Hercules and co-workers [14] first reported production of gas-phase ruthenium trisbipyridine, $\left[\mathrm{Ru}(\mathrm{bpy})_{3}\right]^{1+}$, using LD (Nd:YAG at $265 \mathrm{~nm}$ ) in 1985. The dominant peaks observed were at $\mathrm{m} / \mathrm{z} 449$ and 414, which correspond to $\left[\mathrm{Ru}(\mathrm{bpy})_{2} \mathrm{Cl}\right]^{1+}$ and $\left[\mathrm{Ru}(\mathrm{bpy})_{2}\right]^{1+}$, respectively. In 1988, Beavis et al. [15] employed LD time-of-flight (TOF) to analyze tris(2,2'-bipyridyl)ruthenium(II) acetate, $\left[\mathrm{Ru}(\mathrm{bpy})_{3}\right]\left(\mathrm{CH}_{3} \mathrm{CO}_{2}\right)_{2}$, using a $\mathrm{CO}_{2}(10.6 \mu \mathrm{m})$ TEA laser. The spectrum showed peak clusters that were assigned to gas-phase ions of $\left[\mathrm{Ru}(\mathrm{bpy})_{3}\right]^{1+}(\mathrm{m} / \mathrm{z}=570)$ and $\left[\mathrm{Ru}(\mathrm{bpy})_{2}\right]^{1+}(\mathrm{m} / \mathrm{z}=414)$. The authors also noted evidence of pyridine derived fragments.

In 2001, Hunsucker et al. [16] systematically compared direct LD with MALDI of metal-polypyridyl 
complexes. They analyzed a variety of mono- and trimetallic compounds with TOF-MS using both Nd: YAG (355 nm) and $\mathrm{N}_{2}(337 \mathrm{~nm})$ lasers. For both LD and MALDI, they observed a significant amount of counterion attachment to form a broad range of pseudomolecular ion $\left[\mathrm{M}-\mathrm{nPF}_{6}\right]^{1+}$ peaks. Simple ligand losses were also reported. The primary difference between LD and MALDI were the addition of matrix adducts in the MALDI spectra. Comparison of a variety of matrices revealed that 2,5-dihydroxybenzoic acid (DHB) formed the most adduct peaks, while sinapinic acid (SA) produced very few matrix adduct peaks. Additionally, they reported that matrix-to-analyte ratios between 500:12000:1 gave the best results regardless of matrix.

The results obtained using fast atom bombardment mass spectrometry (FAB-MS) [9-13] are in contrast to those reported for LD [14, 15] and MALDI [16]. Freas and co-workers [13] analyzed a series of hexafluorophosphate $\left(\mathrm{PF}_{6}^{-}\right)$salts of ruthenium polypyridyl complexes. Spectra obtained directly from samples in a 3-nitrobenzyl alcohol matrix produced predominantly singly-charged ions and revealed simple ligand losses, counter ion adducts, $\mathrm{F}$ adducts, and losses of $\mathrm{H}$. The observation of hydrogen losses was possible with the resolving power of the magnetic sector instrument. The intact doubly-charged ruthenium complexes were also observed similar to other FAB-MS results [10]. Cerny et al. [12] reported that the most consistent peak in FAB-MS spectra of $\mathrm{Ru}$ and Os bipyridyl complexes corresponded to $\left[\mathrm{M}(\mathrm{bpy})_{2}-\mathrm{H}\right]^{1+}$.

In this paper, we present direct LD-FTMS and MALDI-FTMS data of Ru and Os trisbipyridyl complexes. FTMS provides high mass accuracy combined with superior resolution to facilitate accurate mass assignment of spectral peaks derived from these compounds. Additionally, we have compared results using different counter ions for the metal-bipyridyl complexes as well as two matrices, SA and DHB. Our results demonstrate that the choice of matrix and ionization method is critical for producing intact molecular ions.

\section{Experimental}

\section{Materials}

$\left[\mathrm{Ru}(\mathrm{bpy})_{3}\right]\left(\mathrm{PF}_{6}\right)_{2}$ (bpy $=$ bipyridine) was prepared according to standard procedures [17]. [Os $\left.(\mathrm{bpy})_{3}\right]\left(\mathrm{PF}_{6}\right)_{2}$ was synthesized according to the procedure by Constable et al. [18]. $\left[\mathrm{Ru}(\mathrm{bpy})_{3}\right] \mathrm{Cl}_{2}$ and $\left[\mathrm{Os}(\mathrm{bpy})_{3}\right] \mathrm{Cl}_{2}$ were prepared from the $\mathrm{PF}_{6}^{-}$salt by anion exchange using Dowex-1 (Chloride form) exchange resin (Sigma, St. Louis, MO). Acetonitrile (HPLC grade) was purchased from Aldrich Chemical Co. (Milwaukee, WI). Additionally, $\left[\mathrm{Ru}(\mathrm{bpy})_{3}\right] \mathrm{Cl}_{2}$ was purchased from Aldrich Chemical Co. $\left[\mathrm{Ru}(\mathrm{bpy})_{3}\right](\text { triflate })_{2}, \quad\left[\mathrm{Ru}(\mathrm{bpy})_{3}\right](\mathrm{SCN})_{2}$, and $\left[\mathrm{Ru}(\mathrm{bpy})_{3}\right]\left(\mathrm{BF}_{4}\right)_{2}$ were synthesized by previous members of the Durham research group. Matrices 3,5-dimethoxy-4-hydroxycinnamic acid [common name $=$ sina-

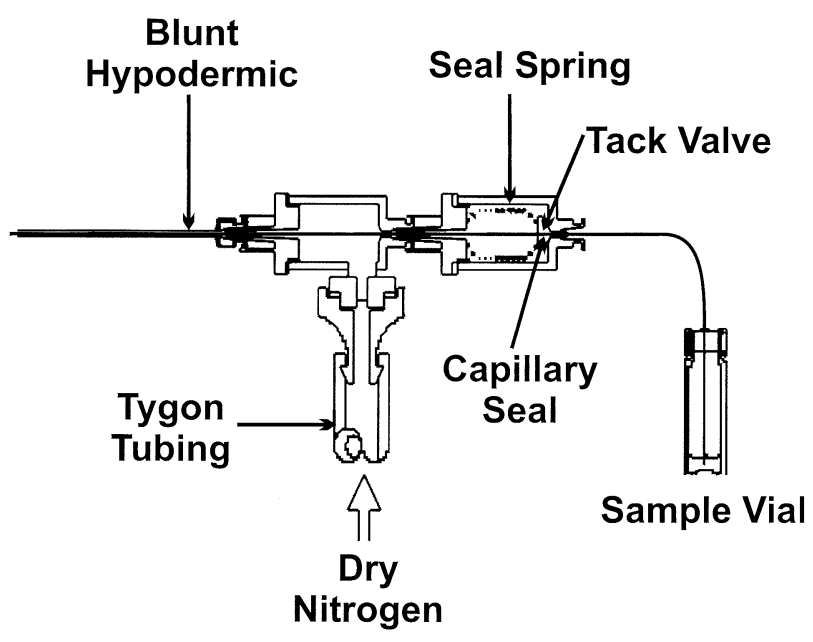

Figure 1. Aerospray apparatus for preparation of MALDI-FTMS samples.

pinic acid (SA)] and 2,5-dihydroxybenzoic acid (DHB) were purchased from Aldrich Chemical Co.

\section{Sample Preparation}

Laser desorption. Approximately $1 \mathrm{mg}$ of each metalbipyridine complex was applied to a $1 / 4$-inch piece of double-sided sticky tape, 3M (St. Paul, MN) attached to a 316 SS probe tip (19 $\mathrm{mm}$ diameter.).

MALDI. $\left[\mathrm{Ru}(\mathrm{bpy})_{3}\right] \mathrm{Cl}_{2},\left[\mathrm{Ru}(\mathrm{bpy})_{3}\right]\left(\mathrm{PF}_{6}\right)_{2},\left[\mathrm{Os}(\mathrm{bpy})_{3}\right] \mathrm{Cl}_{2}$, and $\left[\mathrm{Os}(\mathrm{bpy})_{3}\right]\left(\mathrm{PF}_{6}\right)_{2}$ were each dissolved in acetonitrile. Either sinapinic acid (SA) or 2,5-dihydroxybenzoic acid (DHB) was added to produce a molar ratio of 1000:1 (matrix:analyte). A saturated solution of the matrix was prepared and aerosprayed onto 316 SS probe tips as a base coat using the apparatus shown in Figure 1. Each MALDI sample was then sprayed on top of the base coat. The spray apparatus was made by adapting the valves of two 2-way valve Luer-Lok syringes (Becton Dickinson, Franklin Lakes, NJ). All of the tack valves and springs were removed except for the one in the tip used for the capillary inlet. A hole was drilled through the tack valve to allow a $0.32 \mathrm{~mm}$ i.d. deactivated fused-silica capillary (Restek, State College, PA) to be inserted. The capillary then passes straight through the other syringe, which is used as a gas chamber. Dry nitrogen gas passes around the capillary allowing the sample in the vial to be sprayed in a fine mist according to the Bernoulli principle [19]. This aerospray design has several advantages over previous designs [20]: (1) it is simple to construct, (2) it allows for faster clean up and replacement of the capillary, and (3) it has improved spraying consistency because of the straightthrough capillary and large gas chamber design.

\section{LD/MALDI FTMS}

Instrumentation. LD and MALDI spectra were obtained on a laboratory-built imaging FTMS system at 
the Idaho National Engineering and Environmental Laboratory (INEEL), which has previously been described in detail [21, 22]. Briefly, the INEEL FTMS incorporates a 7 T Oxford (Oxford, England) superconducting magnet, a 2-inch cubic cell, and an Odyssey control and data acquisition system (Finnigan FT/MS, Bremen, Germany). A Nd:YAG laser (Continuum, Santa Clara, CA) operating at $355 \mathrm{~nm}$ with a $6 \mathrm{~ns}$ pulse width was used for desorption/ionization. The laser fluence was set at $1 \times 10^{8} \mathrm{~W} \mathrm{~cm}^{-2}$ for $\sim 6 \mu \mathrm{m}$ diameter spots.

Parameters. LD and MALDI spectra were recorded in the positive mode. The sample was located $0.5 \mathrm{~cm}$ from the front trap plate. During the ionization event, the potential on the front and rear trap plates was maintained at $0 \mathrm{~V}$. After ionization, a trapping potential of $+0.5 \mathrm{~V}$ was applied to both front and rear trap plates and maintained until the quench event at the end of the sequence. A delay of $0.5 \mathrm{~s}$ was imposed prior to application of a chirp excitation over the range of 50 to $800 \mathrm{kHz}$ with a sweep rate of $360 \mathrm{~Hz} / \mu \mathrm{s}$. Only positive mode data are reported because only counterions were observed in the negative mode. After a delay of $0.6 \mathrm{~ms}$, the ions were detected in direct mode using $64 \mathrm{~K}$ data points. Data were then baseline corrected, Hamming apodized, zero filled, and Fourier transformed to produce the mass spectra. Pressure during analysis was 5 $\times 10^{-8}$ torr. The system was externally calibrated using sodium-attached polyethylene glycol 1000.

\section{Results}

Laser desorption spectra derived from $\left[\mathrm{Ru}(\mathrm{bpy})_{3}\right] \mathrm{Cl}_{2}$ and $\left[\mathrm{Ru}(\mathrm{bpy})_{3}\right]\left(\mathrm{PF}_{6}\right)_{2}$ are shown in Figure $2 \mathrm{a}$ and $\mathrm{b}$, respectively. Common peaks in both spectra include the molecular ion $\left(\left[\mathrm{Ru}(\mathrm{bpy})_{3}\right]^{1+}\right)$ isotopic cluster at $\mathrm{m} / \mathrm{z} 569$ and the dominant fragment $\left(\left[\mathrm{Ru}(\mathrm{bpy})_{2}\right]^{1+}\right)$ at $m / z 413$. Further investigations of these peaks show isotopic distributions that do not correlate with theoretical spectra. The clusters around $m / z 569$ and 413 show loss of 1 to $3 \mathrm{H}$, which shifts the apparent monoisotopic peak to lower values. Close examination of these peaks shows splitting, which also suggests that the peaks result from a mixture of ions. Additionally, the mass accuracy is poor $(\sim 20 \mathrm{ppm})$ compared to calibration spectra or those obtained using MALDI with sinapinic acid $(<3$ ppm) as described below.

In Figure 2a, gas-phase attachment of $\mathrm{Cl}$ to $\left[\mathrm{Ru}(\mathrm{bpy})_{2}\right]^{1+}$ is observed at $\mathrm{m} / \mathrm{z} 448$ and 484 where $1 \mathrm{Cl}$ and $2 \mathrm{Cl}$ have attached, respectively. The $\mathrm{PF}_{6}$ complex also shows counter ion addition to ruthenium bisbipyridine at $m / z$ 557; however, no peak correlating to $\left[\mathrm{Ru}(\mathrm{bpy})_{2}+2 \mathrm{PF}_{6}\right]^{1+}$ was observed (Figure $2 \mathrm{~b}$ ). The $\mathrm{PF}_{6}$ complex also shows $\mathrm{F}$ addition to $\left[\mathrm{Ru}(\mathrm{bpy})_{2}\right]^{1+}$ at $\mathrm{m} / \mathrm{z}$ 433. Beavis et al. [15] have shown that a bipyridine ligand may also fragment, releasing a pyridine ring. Evidence of these interactions were observed at $m / z 490$ $\left(\left[\mathrm{Ru}(\mathrm{bpy})_{2}+\mathrm{py}\right]^{1+}, \mathrm{py}=\right.$ pyridine $)$ for both the $\mathrm{Cl}$ and

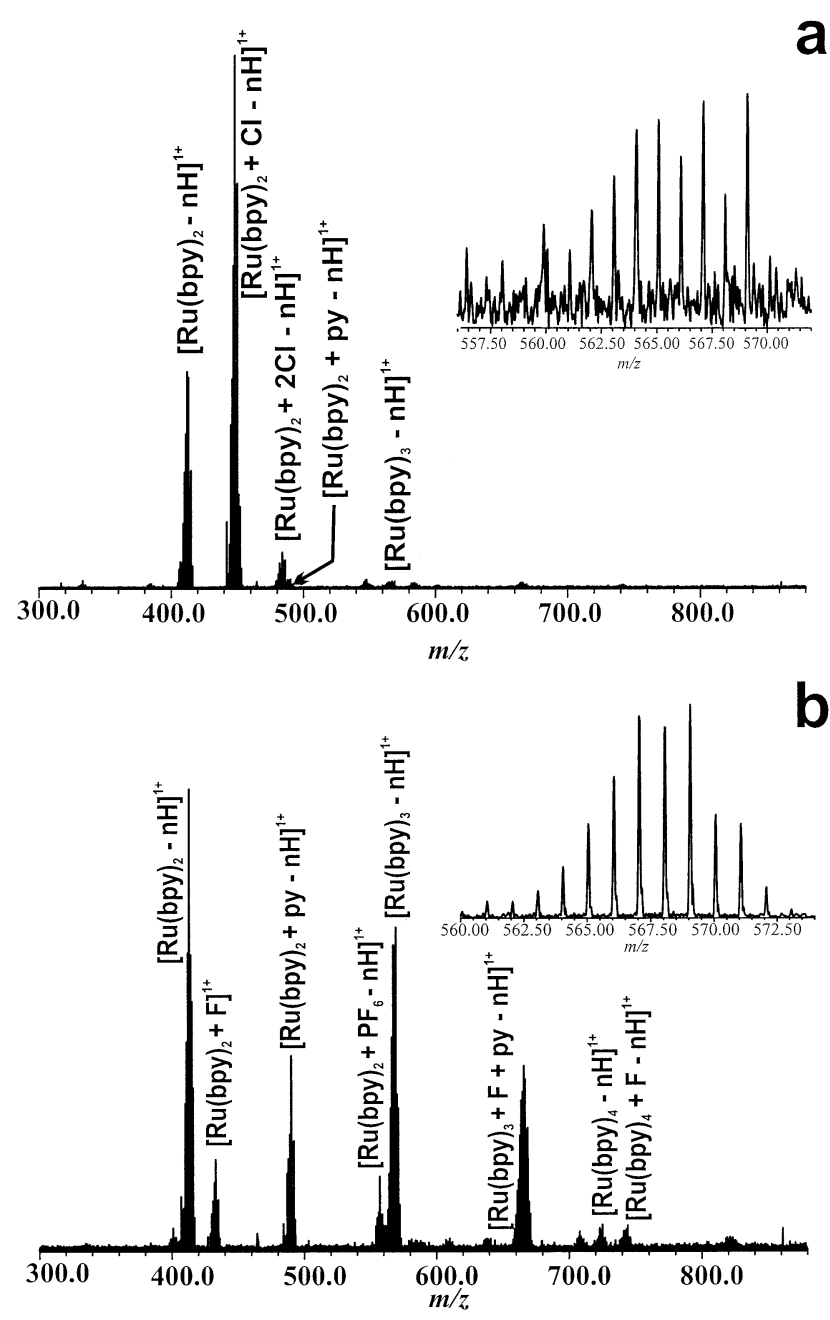

Figure 2. LD spectra of (a) $\left[\mathrm{Ru}(\mathrm{bpy})_{3}\right] \mathrm{Cl}_{2}$ and (b) $\left[\mathrm{Ru}(\mathrm{bpy})_{3}\right]\left(\mathrm{PF}_{6}\right)_{2}$. Insets are expanded view of $\mathrm{M}^{+}$isotopic clusters. Each spectrum is a composite of nine co-added spectra.

$\mathrm{PF}_{6}$ salts; however, pyridine attachment to the trisbipyridine is only observed for the $\mathrm{PF}_{6}$ at $\mathrm{m} / \mathrm{z} 666$ $\left(\left[\mathrm{Ru}(\mathrm{bpy})_{3}+\mathrm{py}+\mathrm{F}\right]^{1+}\right)$, which suggests that there may be sufficient free py generated to react in the gas phase or desorption plume. Other peaks included in Figure $2 \mathrm{~b}$ are $m / z 725\left(\left[\mathrm{Ru}(\text { bpy })_{4}-n \mathrm{H}\right]^{1+}\right)$ and $m / z 743\left(\left[\mathrm{Ru}(\mathrm{bpy})_{4}\right.\right.$ $\left.+\mathrm{F}-n \mathrm{H}]^{1+}\right)$, where $n=1-3$. The $\left[\mathrm{Ru}(\mathrm{bpy})_{4}\right]^{1+}$ complexes do not appear in the spectra of the chloride salt.

Figure $3 a$ and $b$ are the LD mass spectra for $\left[\mathrm{Os}(\mathrm{bpy})_{3}\right] \mathrm{Cl}_{2}$ and $\left[\mathrm{Os}(\mathrm{bpy})_{3}\right]\left(\mathrm{PF}_{6}\right)_{2}$, respectively. Less fragmentation is observed in the LD spectra of the Os complexes than that observed for the Ru complexes. In both spectra, the dominant species is that of the molecular ion cluster, $\left[\mathrm{Os}(\mathrm{bpy})_{3}\right]^{1+}$, at $\mathrm{m} / \mathrm{z}$ 659. The common fragment is due to loss of one bipyridine ligand giving rise to a peak at $m / z$ 504. Another common fragment seen in both spectra appears at $m / z 580$, which corresponds to $\left[\mathrm{Os}(\mathrm{bpy})_{2}+\mathrm{py}\right]^{1+}$. The intensity of these peaks strengthens with increasing laser fluence. As with the LD spectra of the $\mathrm{Ru}$ complexes, experimental isotopic distributions for the $[\mathrm{M}]^{1+}$ and the $[\mathrm{M}-\mathrm{bpy}]^{1+}$ 

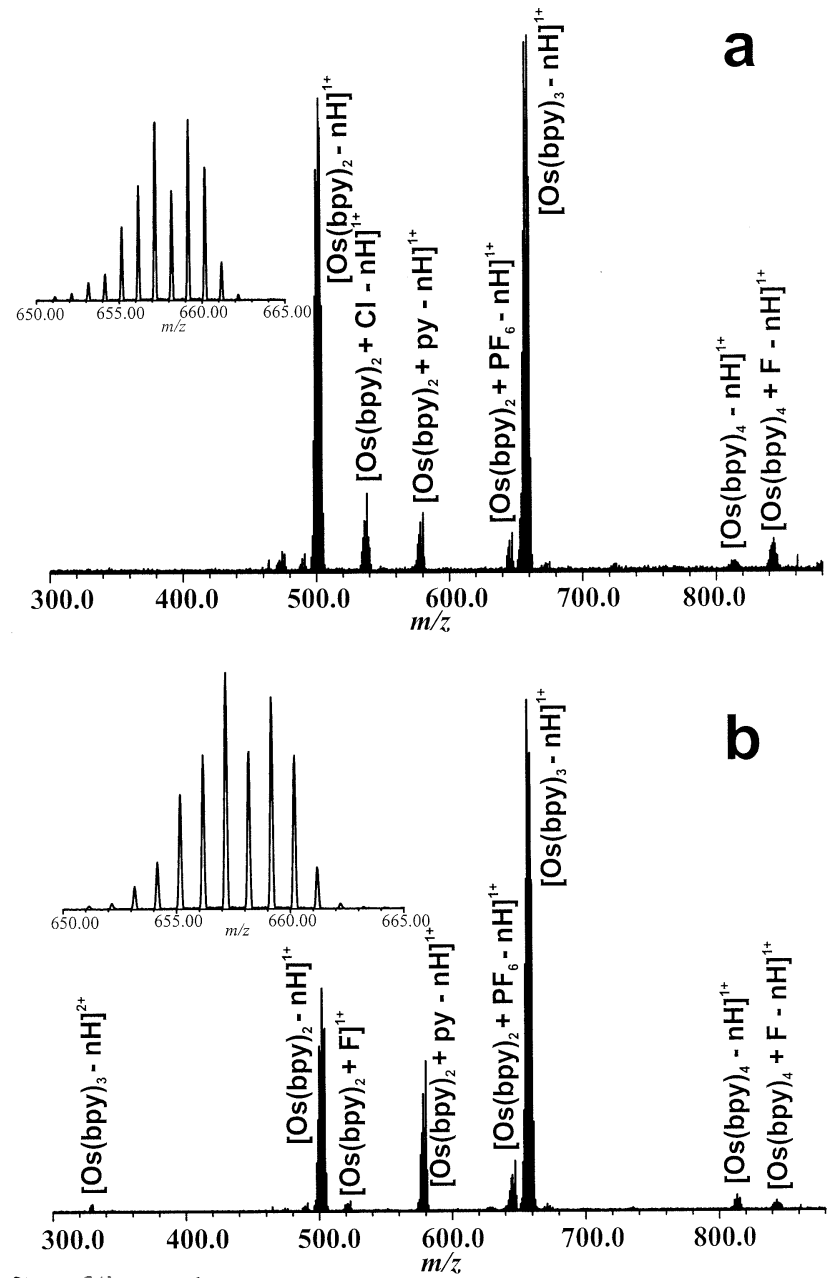

Figure 3. LD spectra of (a) $\left[\mathrm{Os}(\mathrm{bpy})_{3}\right] \mathrm{Cl}_{2}$ and (b) $\left[\mathrm{Os}(\mathrm{bpy})_{3}\right]\left(\mathrm{PF}_{6}\right)_{2}$. Insets are expanded view of $\mathrm{M}^{+}$isotopic clusters. Each spectrum is a composite of nine co-added spectra.

peaks do not correlate with theoretical distributions and are probably the result of $\mathrm{H}$ losses.

The chloride salt of Os (Figure 3a) shows a similar attachment of $\mathrm{Cl}$ to the $\left[\mathrm{Os}(\mathrm{bpy})_{2}\right]^{1+}$ at $\mathrm{m} / \mathrm{z} 538$ as seen in $\mathrm{LD}$ spectra of $\left[\mathrm{Ru}(\mathrm{bpy})_{3}\right] \mathrm{Cl}_{2}$; however, attachment of a second $\mathrm{Cl}$ to produce $\left[\mathrm{Os}(\mathrm{bpy})_{2}+2 \mathrm{Cl}\right]^{1+}$ was not observed. The $\mathrm{PF}_{6}$ salt of Os (Figure $3 \mathrm{~b}$ ) shows analogous results to those in Ru. Peaks at $\mathrm{m} / z 523\left[\mathrm{Os}(\mathrm{bpy})_{2}\right.$ $+\mathrm{F}^{1+}$ and at $m / z 647\left[\mathrm{Os}(\mathrm{bpy})_{2}+\mathrm{PF}_{6}\right]^{1+}$ are comparable to peaks observed in $\left[\mathrm{Ru}(\mathrm{bpy})_{3}\right]\left(\mathrm{PF}_{6}\right)_{2}$ laser desorption spectra. The $\mathrm{Cl}_{2}$ salt spectrum also shows a peak at $\mathrm{m} / \mathrm{z} 647$ indicating that $\mathrm{PF}_{6}^{-}$was not completely removed during anionic exchange. Other clusters included in both spectra are those at $\mathrm{m} / \mathrm{z} 813$ and 843 , which have nominal masses that correlate with structures of $\left[\mathrm{Os}(\mathrm{bpy})_{4}-n \mathrm{H}\right]^{1+}$ and $\left[\mathrm{Os}(\mathrm{bpy})_{4}+\mathrm{F}-n \mathrm{H}\right]^{1+}$, respectively.

LD spectra of $\left[\mathrm{Ru}(\mathrm{bpy})_{3}\right]\left(\mathrm{CF}_{3} \mathrm{SO}_{3}\right)_{2},\left[\mathrm{Ru}(\mathrm{bpy})_{3}\right](\mathrm{SCN})_{2}$, and $\left[\mathrm{Ru}(\mathrm{bpy})_{3}\right]\left(\mathrm{BF}_{4}\right)_{2}$ showed similar results to the $\mathrm{Cl}$ and $\mathrm{PF}_{6}^{-}$salts of ruthenium. The common fragment seen in all spectra is the mass cluster around $\mathrm{m} / \mathrm{z} 414$. All spectra showed loss of 1 to $3 \mathrm{H}$ atoms. No counterion
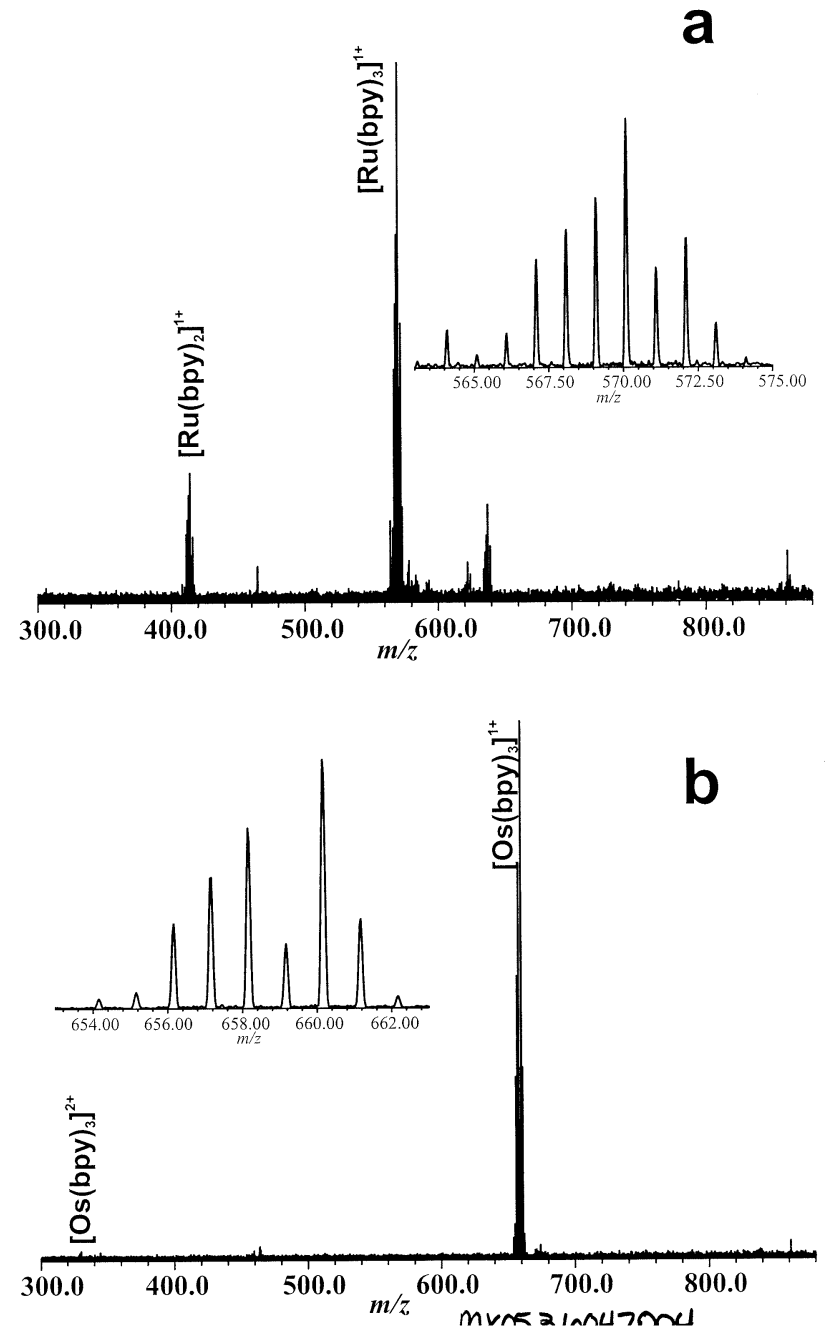

Figure 4. MALDI spectra of (a) $\left[\mathrm{Ru}(\mathrm{bpy})_{3}\right] \mathrm{Cl}_{2}$ and (b) $\left[\mathrm{Os}(\mathrm{bpy})_{3}\right] \mathrm{Cl}_{2}$ with sinapinic acid as matrix. Insets are expanded view of $\mathrm{M}^{+}$isotopic clusters. Each spectrum is a composite of nine co-added spectra.

attachment was observed for the $\mathrm{SCN}$ and $\mathrm{CF}_{3} \mathrm{SO}_{3}$ salts. The $\mathrm{BF}_{4}$ salt shows analogous results to the $\mathrm{PF}_{6}$ complex with similar loss of $\mathrm{F}$ from the tetrafluoroborate complex and F-attachment to $\left[\mathrm{Ru}(\mathrm{bpy})_{2}\right]^{1+}$.

MALDI spectra of the ruthenium and osmium complexes show similar results for the $\mathrm{Cl}$ and $\mathrm{PF}_{6}$ salts. For convenience only the spectra for $\left[\mathrm{Ru}(\mathrm{bpy})_{3}\right] \mathrm{Cl}_{2}$ and $\left[\mathrm{Os}(\mathrm{bpy})_{3}\right] \mathrm{Cl}_{2}$ using sinapinic acid as matrix are presented in Figure 4. Figure 4a shows the MALDI mass spectrum of $\left[\mathrm{Ru}(\mathrm{bpy})_{3}\right] \mathrm{Cl}_{2}$. Analogous peaks are observed at $\mathrm{m} / z$ $570.01\left(\left[\mathrm{Ru}(\mathrm{bpy})_{3}\right]^{1+}\right)$ and $\mathrm{m} / \mathrm{z} 414.04$ $\left(\left[\mathrm{Ru}(\mathrm{bpy})_{2}\right]^{1+}\right)$ as seen in the laser desorption spectra. Unlike the LD results, the isotopic patterns were in close agreement with the calculated isotopic envelope for $\left[\mathrm{Ru}(\mathrm{bpy})_{3}\right]^{1+}$, which indicates that $\mathrm{H}$ loss did not occur. Lower laser fluence, approximately a factor of seven, produced less fragmentation; thereby limiting the formation of $\left[\mathrm{Ru}(\mathrm{bpy})_{2}\right]^{1+}$. Also observed are adducts of sinapinic acid to the Ru complex at $\mathrm{m} / \mathrm{z}$ values 622 and 637. However, no counterion adduct peaks were observed for either of the two salts. 
The MALDI spectrum of $\left[\mathrm{Os}(\mathrm{bpy})_{3}\right] \mathrm{Cl}_{2}$ is illustrated in Figure $4 \mathrm{~b}$. The monoisotopic ion mass for $\left[\mathrm{Os}(\mathrm{bpy})_{3}\right]^{1+}$ $(\mathrm{m} / \mathrm{z}$ 660.17) is the dominant peak in these spectra. A cluster at $m / z 504.10\left(\left[\mathrm{Os}(\mathrm{bpy})_{2}\right]^{1+}\right.$, not shown) does appear in spectra obtained with higher laser fluences. As in the MALDI spectra of Ru (Figure 4a), no counterion attachment is observed. Interestingly, both $\mathrm{Cl}$ and $\mathrm{PF}_{6}$ spectra also show small peaks at $\mathrm{m} / \mathrm{z} 330.08$, which is the monoisotopic ion mass for the doubly-charged molecular ion species, $\left[\mathrm{Os}(\mathrm{bpy})_{3}\right]^{2+}$. These peaks were confirmed by the $0.5 \mathrm{Da}$ separations of the isotopes. This is uncommon for MALDI generated spectra, which primarily produce singly charged species [23].

In general, MALDI spectra of the ruthenium and osmium complexes using DHB as matrix were similar to those produced using sinapinic acid. While the overall fragmentation patterns were the same, the spectra were more complex because of additional matrix adduct peaks. Additionally, the DHB experimental isotopic distributions did not match the theoretical values as did the spectra obtained using sinapinic acid. Instead, the DHB isotopic distributions revealed the loss of 1-3 $\mathrm{H}$ atoms, similar to the LD results.

\section{Discussion}

For the ruthenium compounds, there are both similarities and differences between the LD spectra derived from the $\mathrm{Cl}$ and $\mathrm{PF}_{6}$ salt (Figure 2). Even for similar ions, the peak intensities were greater for ions derived from $\left[\mathrm{Ru}(\mathrm{bpy})_{3}\right]\left(\mathrm{PF}_{6}\right)_{2}$ than those produced from $\left[\mathrm{Ru}(\mathrm{bpy})_{3}\right] \mathrm{Cl}_{2}$ under the same conditions. For example, while $\left[\mathrm{Ru}(\mathrm{bpy})_{3}\right] \mathrm{Cl}_{2}$ showed little production of the molecular ion $\left(\left[\mathrm{Ru}(\mathrm{bpy})_{3}\right]^{1+}\right)$, the $\mathrm{PF}_{6}$ salt generates this ion more abundantly. This holds true for other ions in both spectra, such as $\left[\mathrm{Ru}(\mathrm{bpy})_{2}\right]^{1+}$ and the $\left[\mathrm{Ru}(\mathrm{bpy})_{2}+\right.$ py $]^{1+}$ at $m / z 413.02$ and 490.034 , respectively.

Counterion attachment was observed in both the $\mathrm{Cl}_{2}$ and $\mathrm{PF}_{6}$ spectra. For the $\mathrm{Cl}^{-}$salt, the dominant peak in the spectrum correlates with $\left[\mathrm{Ru}(\mathrm{bpy})_{2}+\mathrm{Cl}\right]^{1+}$ (Figure 2a). A less intense peak is observed for the two $\mathrm{Cl}$ attached at $m / z$ 483.98. Balasanmugam et al. [14] also observed the $\left[\mathrm{Ru}(\mathrm{bpy})_{2}+2 \mathrm{Cl}\right]^{1+}$ ion using LD desorption with a Nd:YAG laser (266 nm). They explain that the production of this ion is a result of photo-oxidation of $\left[\mathrm{Ru}(\mathrm{bpy})_{3}\right] \mathrm{Cl}_{2}$, which has known to occur in solution. The photo-oxidation to form the chloride attached peaks may also explain the low abundance of the $\left[\mathrm{Ru}(\mathrm{bpy})_{3}\right]^{1+}$. For $\left[\mathrm{Ru}(\mathrm{bpy})_{3}\right]\left(\mathrm{PF}_{6}\right)_{2}$, a peak was observed for the $\left[\mathrm{Ru}(\mathrm{bpy})_{2}+\mathrm{PF}_{6}\right]^{1+}$ complex, but not for the $\left[\mathrm{Ru}(\mathrm{bpy})_{2}\right.$ $\left.+2 \mathrm{PF}_{6}\right]^{1+}$ (Figure $2 \mathrm{~b}$ ). These results are contrary to what is seen in the $\mathrm{Cl}$ salts. Attachment of only one $\mathrm{PF}_{6}$ is consistent with the results by FAB-MS that showed spectra with only one counterion attachment [13].

Other remaining peaks in the $\left[\mathrm{Ru}(\mathrm{bpy})_{3}\right]\left(\mathrm{PF}_{6}\right)_{2}$ spectrum that do not appear in the $\left[\mathrm{Ru}(\mathrm{bpy})_{3}\right] \mathrm{Cl}_{2}$ spectrum are those at $m / z$ values $433,665,725$, and 743 . The cluster at $m / z 433$ corresponds to $\left[\mathrm{Ru}(\mathrm{bpy})_{2}+\mathrm{F}\right]^{1+}$. The occurrence of this peak was not unexpected because similar dissociation of $\mathrm{F}$ from a $\mathrm{PF}_{6}$ has been observed in FAB-MS experiments [13]. Attachement of F does lead to the production of other ions in the gas phase such as those at $m / z 665\left(\left[\mathrm{Ru}(\mathrm{bpy})_{3}+\mathrm{F}+\text { py }\right]^{1+}\right)$ and $m / z 743\left(\left[\mathrm{Ru}(\mathrm{bpy})_{4}+\mathrm{F}-n \mathrm{H}\right]^{1+}\right)$. The cluster center around $m / z 725$ corresponds to $\left[\mathrm{Ru}(\mathrm{bpy})_{4}-n \mathrm{H}\right]^{1+}$. The presence of four bipyridine ligands on one Ru suggests that two of the bipyriding ligands are monodentate instead of bidentate.

If the isotopic distributions of the ion clusters are closely evaluated as in Figure 5 for $\left[\mathrm{Ru}(\mathrm{bpy})_{2}\right]^{1+}$, the pattern for the LD spectrum (Figure $5 b$ ) does not match the theoretical spectrum in Figure 5a. Isotopic patterns in FTMS, especially those of ions formed by desorption processes, often do not match the theoretical distributions. The observed isotopic peak pattern can be explained by a linear combination of abundances derived form a series of $\mathrm{H}$ losses producing $\left[\mathrm{Ru}(\mathrm{bpy})_{2}-\mathrm{H}\right]^{1+},\left[\mathrm{Ru}(\mathrm{bpy})_{2}\right.$ $-2 \mathrm{H}]^{1+}$, and $\left[\mathrm{Ru}(\mathrm{bpy})_{2}-3 \mathrm{H}\right]^{1+}$. A linear combination of abundances of these peaks corresponding to 49,41 , and $10 \%$, respectively, gives an isotopic pattern similar to the experimental distribution as illustrated in Figure 6. Addition of these ions to the isotopic cluster accounts for the extra peaks observed at $m / z 405,406$, and 407 as well as the apparent shift in the location of the monoisotopic peak to a lower $m / z$ value. The percentage of $\left[\mathrm{Ru}(\mathrm{bpy})_{2}\right]^{1+}$ contributing to the isotopic pattern is $<1 \%$.

Unlike the trisbipyridine ruthenium salts, LD spectra of $\left[\mathrm{Os}(\mathrm{bpy})_{3}\right] \mathrm{Cl}_{2}$ and $\left[\mathrm{Os}(\mathrm{bpy})_{3}\right]\left(\mathrm{PF}_{6}\right)_{2}$ are very similar (Figure 3). Both salts show intense monoisotopic molecular ion peaks at $m / z 660\left(\left[\mathrm{Os}(\mathrm{bpy})_{3}\right]^{1+}\right)$ and fragments at $m / z 502\left(\left[\mathrm{Os}(\mathrm{bpy})_{2}\right]^{1+}\right)$ and $m / z 580\left(\left[\mathrm{Os}(\mathrm{bpy})_{2}+\mathrm{py}^{1+}\right)\right.$. Losses of $n \mathrm{H}$ ( $n=0$ to 3 ) appear to have occurred according to the isotopic distributions. Cerny et al. [12] reported loss of one $\mathrm{H}$ for similar peaks using FAB-MS. Another peak included in spectra from both salts is $\mathrm{m} / \mathrm{z}$ 647 , which corresponds to $\left[\mathrm{Os}(\mathrm{bpy})_{2}+\mathrm{PF}_{6}\right]^{1+}$. Since the [Os(bpy $\left.)_{3}\right] \mathrm{Cl}_{2}$ is made from the $\mathrm{PF}_{6}$ salt by anionic exchange, this peak in the chloride spectrum is likely a result of incomplete purification. Clusters at $\mathrm{m} / \mathrm{z} 813$ and 843 also appear in both Os complexes. These peaks correlated to $\left[\mathrm{Os}(\mathrm{bpy})_{4}-n \mathrm{H}\right]^{1+}$ and $\left[\mathrm{Os}(\mathrm{bpy})_{4}+\mathrm{F}-\right.$ $n \mathrm{H}]^{1+} \quad(n=0$ to 3$)$, respectively. Because $\left[\mathrm{Ru}(\mathrm{bpy})_{3}\right]\left(\mathrm{PF}_{6}\right)_{2}$ produces analogous peaks, but other counterion complexes do not, the $\mathrm{PF}_{6}$ may play a role in the formation of these larger ion clusters. Even though $\left[\mathrm{Os}(\mathrm{bpy})_{3}\right] \mathrm{Cl}_{2}$ was contaminated with the $\mathrm{PF}_{6}$, a substantial peak was observed at $m / z 538$. This peak correlates with $\left[\mathrm{Os}(\mathrm{bpy})_{2}+\mathrm{Cl}\right]^{1+}$, which is comparable to results from $\left[\mathrm{Ru}(\mathrm{bpy})_{3}\right] \mathrm{Cl}_{2}$. $\left[\mathrm{Os}(\mathrm{bpy})_{3}\right]\left(\mathrm{PF}_{6}\right)_{2}$ also showed similar counterion attachment as those seen in spectrum of $\left[\mathrm{Ru}(\mathrm{bpy})_{3}\right]\left(\mathrm{PF}_{6}\right)_{2}$ (Figure $2 \mathrm{~b}$ ). The peak at $m / z 523\left(\left[\mathrm{Os}(\mathrm{bpy})_{2}+\mathrm{F}^{1+}\right]^{2}\right)$ is parallel to the peak at $m / z$ 433 in the LD spectra of $\left[\mathrm{Ru}(\mathrm{bpy})_{3}\right]\left(\mathrm{PF}_{6}\right)_{2}$. Examination of the isotopic distribution of $\left[\mathrm{Ru}(\mathrm{bpy})_{2}+\mathrm{F}\right]^{1+}$ and $\left[\mathrm{Os}(\mathrm{bpy})_{2}+\mathrm{F}\right]^{1+}$ revealed no loss of $\mathrm{H}$.

A feature common to all of the LD spectra is the loss of 1 to 3 hydrogens for most of the ion clusters. Beavis et al. [15] did not report observation of losses of $\mathrm{H}$ for 

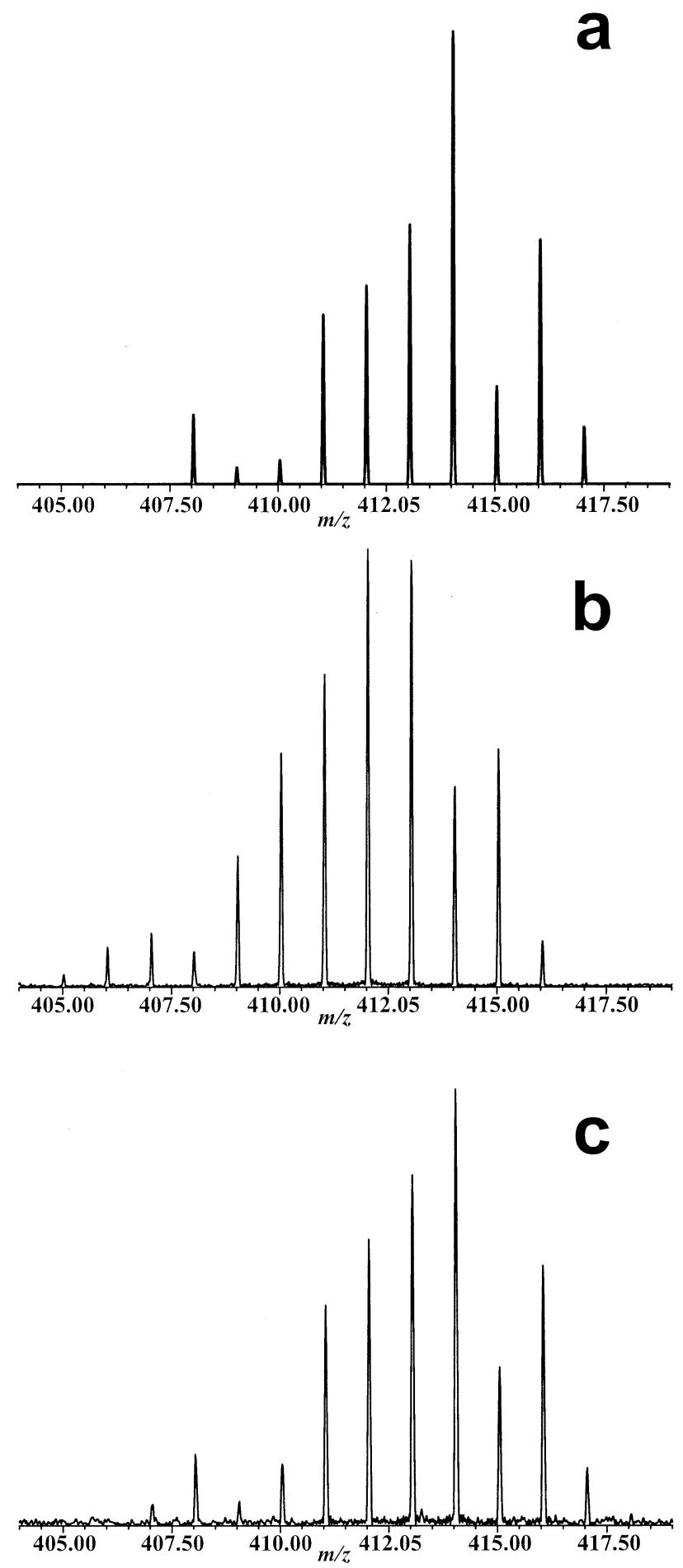

Figure 5. Isotopic patterns for peak cluster at $\mathrm{m} / \mathrm{z} 414$ derived from $\left[\mathrm{Ru}(\mathrm{bpy})_{3}\right] \mathrm{Cl}_{2} ;\left(\right.$ a) theoretical distribution for $\left[\mathrm{Ru}(\mathrm{bpy})_{2}\right]^{1+}$, (b) experimental LD spectrum, and (c) experimental MALDI spectrum using sinapinic acid as matrix.

$\left[\mathrm{Ru}(\mathrm{bpy})_{3}\right]\left(\mathrm{CH}_{3} \mathrm{CO}_{2}\right)_{2}$ analyzed by laser desorption on a TOF instrument using a TEA $\mathrm{CO}_{2}$ laser $(10.6 \mu \mathrm{m})$. However, due to lower resolution spectrum and reporting of only nominal $\mathrm{m} / \mathrm{z}$ values, it is difficult to tell if $\mathrm{H}$ loss was present. Laser desorption of several bipydine complexes, including $\left[\mathrm{Ru}(\mathrm{bpy})_{3}\right] \mathrm{Cl}_{2}$, were reported by

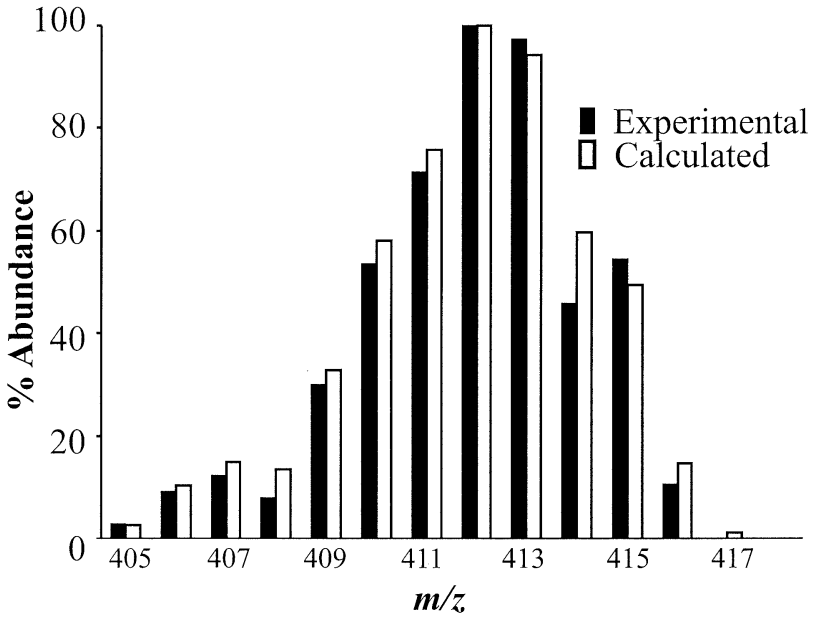

Figure 6. Comparison of experimental (black column) and calculated (white column) isotopic abundances for the peak cluster at $\mathrm{m} / \mathrm{z}$ 414. The calculated abundances are a linear combination of $49 \%\left[\mathrm{Ru}(\mathrm{bpy})_{2}-\mathrm{H}\right]^{1+}, 41 \%\left[\mathrm{Ru}(\mathrm{bpy})_{2}-2 \mathrm{H}\right]^{1+}, 10 \%\left[\mathrm{Ru}(\mathrm{bpy})_{2}-\right.$ $3 \mathrm{H}]^{1+}$, and $<1 \%\left[\mathrm{Ru}(\mathrm{bpy})_{2}\right]^{1+}$.

Balasanmugam et al. [14] using a laser microprobe mass spectrometer coupled with a Nd:YAG laser $(266 \mathrm{~nm})$. Again, poor resolution and nominal $\mathrm{m} / \mathrm{z}$ values prevent identification of $\mathrm{H}$ loss. Also using a TOF mass spectrometer, Hunsucker et al. [16] analyzed multimetallicbipyridyl complexes by direct UV laser desorption (Nd:YAG at $355 \mathrm{~nm}$ ). Again, they did not report observations of $\mathrm{H}$ losses. It is possible that $\mathrm{H}$ loss was not present in the study by Beavis et al. [15] because they used infrared as opposed to ultraviolet laser desorption; however, it is quite likely that loss of $\mathrm{H}$ did occur in the studies using ultraviolet LD [14, 16], but was not observed because of low spectral resolution. Earlier FAB-MS results $[10,12,13]$ using sector instruments did demonstrate loss of one $\mathrm{H}$ for $\left[\mathrm{Ru}(\mathrm{bpy})_{2}\right]^{1+}$. Loss of one $\mathrm{H}$ for $\left[\mathrm{Ru}(\mathrm{bpy})_{3}\right]^{1+}$ was reported by Miller and coworkers [10].

For both $\left[\mathrm{Ru}(\mathrm{bpy})_{3}\right] X_{2}$ and $\left[\mathrm{Os}(\mathrm{bpy})_{3}\right] X_{2}(\mathrm{X}=\mathrm{Cl}$ or $\mathrm{PF}_{6}$ ), the MALDI spectra obtained using sinapinic acid as the matrix gave similar results regardless of counterion (Figure 4). In general, only two main peaks are observed corresponding to $\left[\mathrm{M}(\mathrm{bpy})_{3}\right]^{1+}$ and $\left[\mathrm{M}(\mathrm{bpy})_{2}\right]^{1+}$ (Figure 4). The molecular ion peak for Os occurs in higher abundance than the molecular ion peak for Ru suggesting that the Os complex is more robust, providing greater survival rates during the desorption/ ionization process. Also, unlike the Ru complex, the Os complex does not form matrix adduct peaks. Additionally, the doubly-charged molecular ion for the Os complex, $\left[\mathrm{Os}(\mathrm{bpy})_{3}\right]^{2+}$, is formed in small abundances, while the corresponding peak for $\mathrm{Ru}$ is not observed. Larger abundances of doubly-charged metal-bipyridine complexes have been observed by FAB-MS [10].

The choice of matrix is an integral step in correctly characterizing these species by MALDI mass spectrometry. Figure $5 \mathrm{c}$ shows the isotopic distribution of the $\left[\mathrm{Ru}(\mathrm{bpy})_{2}\right]^{1+}$ ion from the MALDI spectrum of 
$\left[\mathrm{Ru}(\mathrm{bpy})_{3}\right] \mathrm{Cl}_{2}$ using sinapinic acid as the matrix. The isotopic peak pattern is not identical to the theoretical distribution (Figure 5a); however, it does compare better with the theoretical than does the LD spectra (Figure 5b). Studies using 2,5-dihydroxybenzoic acid (DHB) as the matrix revealed poorer results based on the presence of a greater number matrix adducts and additional losses of $\mathrm{H}$ similar to that observed in the LD spectra.

Hunsucker et al. [16] analyzed a number of multimetallic-bipyidyl complexes using a series of proton donating, electron-scavenging, and neutral matrices by TOF. They claimed that sinapinic acid was the best matrix for UV MALDI because it produced the least amount of matrix adducts with metal-polypyridyl complexes. Our higher resolution results not only confirm that SA forms few matrix adducts, but also reduces the $\mathrm{H}$ losses associated with desorption/ionization of metal-bipyridine complexes.

Loss of $\mathrm{H}$ for ruthenium and osmium-bipyridine complexes raises some interesting issues related to the desorption/ionization mechanism and gas-phase nature of these ions. Production of these ions has been observed using fast atom bombardment and now with UV laser desorption. In FAB studies $[10,12,13]$, the $H$ losses were associated predominantly with $\left[\mathrm{M}(\mathrm{bpy})_{2}\right]^{1+}$ ions and were explained by losses of $\mathrm{HF}$ from $\mathrm{PF}_{6}$ or $\mathrm{F}^{-}$ adducts, $\left[\mathrm{M}(\mathrm{bpy})_{2}+\mathrm{PF}_{6}\right]^{1+}$ and $\left[\mathrm{M}(\mathrm{bpy})_{2}+\mathrm{F}\right]^{1+}$, respectively. In our studies, the loss of $\mathrm{H}$ also occurs with the molecular ion species $\left[\mathrm{M}(\mathrm{bpy})_{3}\right]^{1+}$ and does not correlate with $\mathrm{PF}_{6}$ adducts because other counterion species produce the same $\mathrm{H}$ losses. Both FAB and UV LD ionization processes produce highly energetic species that have enough energy to break a $\mathrm{C}-\mathrm{H}$ bond. Therefore there is probably enough energy to also dissociate the metal-nitrogen bond of a bipyridine ligand, rotation of one pyridyl rings about the $\mathrm{C}-\mathrm{C}$ bond between the aromatic rings, and subsequent formation of a M-C bond, which was first suggest by Cerny et al. [12] to explain the FAB results. In solution, this behavior is not common for $\mathrm{Ru}$ or Os, but is observed for other metals such as Ir and Rh [24]. For the loss of one $\mathrm{H}$, this could be justified because a species such as $\left[\mathrm{Ru}(\mathrm{bpy})_{3}\right]^{1+}$ would be a $19 \mathrm{e}^{-}$compound if the electron resides on the ruthenium metal. Rearrangement of one bipyridy ligand to replace a $\mathrm{M}-\mathrm{N}$ bond by a $\mathrm{M}-\mathrm{C}$ bond would produce a species that would satisfy the $18 \mathrm{e}^{-}$rule [25]. However, this justification does not explain the loss of the second and third H's which would formally produce $17 \mathrm{e}^{-}$and $16 \mathrm{e}^{-}$species, respectively. Experimentally, loss of three H's occurs for metal-bipyridine complexes; however, with mass spectrometry alone, one can only speculate as to the electronic and structural nature of these species.

\section{Conclusions}

Our laser desorption results are more consistent with reported FAB-MS studies than with recent LD studies.
In particular is our observation of losses of $\mathrm{H}$. The primary reason is probably due to the higher resolution and mass accuracy of the FTMS compared to the TOF mass analyzers used in the LD studies. Similar to our FTMS studies, the FAB studies were performed with higher resolving power. While loss of one $\mathrm{H}$ can easily be explained in terms of stabilizing the ruthenium complex by following the $18 \mathrm{e}^{-}$rule, it is difficult to explain the loss of the second and third $H$. Mass spectrometry alone cannot fully identify the electronic and structure of the gas-phase ions. Ideally, optical spectroscopy for both laser plume and gas-phase would be would be necessary to elucidate the structure and electronic states of the metals in the ions.

For metal-bipyridine complexes, MALDI is a better choice for producing intact molecular ions than LD. However, the choice of matrix is also critical. Sinapinic acid appears to be an excellent matrix for production of molecular ion species of metal-bipyridine complexes because it produces few adduct ions and minimal $\mathrm{H}$ losses. These results demonstrate that careful attention to ion generation techniques for metal-bipyridines is critical if these compounds are to be used for gas-phase optical detection studies.

\section{Acknowledgments}

The authors thank Ray Ragagukguk of the Durham research group for synthesis of the $\left[\mathrm{Os}(\mathrm{bpy})_{3}\right]\left(\mathrm{PF}_{6}\right)_{2}$, Paul Tremblay at INEEL for technical support, and Dr. Gary S. Groenewold (INEEL) for helpful conversations. JEH thanks the INEEL ACE Fellowship program for funding. The authors also gratefully acknowledge support from the United States Department of Energy, under contract DE-AC07-99ID13727 BBWI.

\section{References}

1. Kalyanasundaram, K. Polypyridyl Complexes of Ruthenium, Osmium, and Iron. Academic Press: London, 1992, pp 105-206.

2. Szulbinski, W. S.; Malato, S. Photocatalytic Wastewater Treatment Using the Zeolite-Y Entrapped Ruthenium Tris-2,2'Bipyridine Complex. Polish J. Chem. 2001, 75, 1543-1551.

3. Sava, G.; Pacor, S.; Bregant, F.; Ceschia, V. Metal Complexes of Ruthenium-A Potential Class of Selective Anticancer Drugs. Anticancer Res. 1991, 11, 1103-1107.

4. Milkevitch, M.; Shirley, B. W.; Brewer, K. J. Mixed-Metal Polymetallic Platinum Complexes Designed to Interact with DNA. Inorg. Chem. Acta 1997, 264, 249-256.

5. Scott, J. R.; Fairris, J. L.; McLean, M.; Wang, K. F.; Sligar, S. G.; Durham, B.; Millett, F. Intramolecular Electron-Transfer Reactions of Cytochrome $B_{5}$ Covalently Bonded to Ruthenium(II) Polypyridine Complexes: Reorganizational Energy and Pressure Effects. Inorg. Chim. Acta 1996, 243, 193-200.

6. Scott, J. R.; McLean, M.; Sligar, S. G.; Durham, B.; Millett, F. Effect of Binding Cytochrome $C$ and Ionic-Strength on the Reorganizational Energy and Intramolecular Electron-Transfer in Cytochrome $B_{5}$ Labeled with Ruthenium(Ii) Polypyridine Complexes. J. Am. Chem. Soc. 1994, 116, 7356-7362.

7. Scott, J. R.; Willie, A.; McLean, M.; Stayton, P. S.; Sligar, S. G.; Durham, B.; Millett, F. Intramolecular Electron-Transfer in Cytochrome $B_{5}$ Labeled with Ruthenium(II) Polypyridine Complexes-Rate Measurements in the Marcus Inverted Region. J. Am. Chem. Soc. 1993, 115, 6820-6824. 
8. Scott, J. R.; Tremblay, P. L.; Durham, B.; Ham, J. E. Design of a Fluorescence Lifetime Detection System for Ions Trapped in a Fourier Transform Mass Spectrometer. Proceeding of the 49th ASMS Conference; Chicago, IL, May, 2001, p A020612.

9. Denti, G.; Serroni, S. Redox Processed of Ruthenium(II) Polypyridine Complexes Induced by Fast-Atom Bombardment Mass Spectrometry. J. Am. Soc. Mass Spectrom. 1993, 4, 306311.

10. Miller, J. M.; Balasanmugam, K.; Nye, J.; Deacon, G. B.; Thomas, N. C. Observation of Doubly Charged Ions in Fast Atom Bombardment Mass Spectrometry: Ruthenium(Ii) Complexes in a Nitrobenzyl Alcohol Matrix. Inorg. Chem. 1987, 26, 560-562.

11. Bojesen, G. Fast Atom Bombardment Mass Spectrometry of Coordination Compounds. Org. Mass Spectrom. 1985, 20, 413415.

12. Cerny, R. L.; Sullivan, B. P.; Bursey, M. M.; Meyer, T. J. Fast Atom Bombardment and Field Desorption Mass Spectrometry of Organometallic Derivatives of Ruthenium(II) and Osmium(II). Inorg. Chem. 1985, 24, 397-401.

13. Liang, X.; Suwanrumpha, S.; Freas, R. B. Fast Atom Bombardment Tandem Mass Spectrometry of (Polypyridyl)Ruthenium(II) Complexes. Inorg. Chem. 1991, 30, 652-658.

14. Balasanmugam, K.; Day, R. J.; Hercules, D. M. Characterization of O-Phenanthroline and 2,2'-Bipyridine Complexes by Laser Mass Spectrometry. Inorg. Chem. 1985, 23, 4477-4483.

15. Beavis, R.; Lindner, J.; Grotenmeyer, J.; Atkinson, I. M.; Keene, F. R.; Knight, A. E. W. $\mathrm{Co}_{2}$-Laser Desorption and Multiphoton Ionization of Tris(2,2'-Bipyridyl)Ruthenium. J. Am. Chem. Soc. 1988, 110, 7534-7535.

16. Hunsucker, S. W.; Watson, R. C.; Tissue, B. M. Characterization of Inorganic Coordination Complexes by Matrix-Assisted
Laser Desorption/Ionization Mass Spectrometry. Rapid Commun. Mass Spectrom. 2001, 15, 1334-1340.

17. Durham, B.; Walsh, J. L.; Carter, C. L.; Meyer, T. J. Synthetic Applications of Photosubstitution Reactions of Poly(Pyridyl) Complexes of Ruthenium(II). Inorg. Chem. 1980, 19, 860-865.

18. Constable, E. C.; Raithby, P. R.; Smit, D. N. The X-Ray Crystal Structure of Tris(2,2'-Bipyridine)Osmium(II) Hexafluorophosphate. Polyhedron 1989, 8, pp 367-369.

19. Shepherd, D. G. Elements of Fluid Mechanics. Harcourt, Brace, and World Inc.: New York, 1965, pp 159-163.

20. Yao, J.; Dey, M.; Pastor, S. J.; Wilkins, C. L. Analysis of High-Mass Biomolecules Using Electrostatic Fields and Matrix-Assisted Laser Desorption/Ionization in a Fourier Transform Mass Spectrometer. Anal. Chem. 1995, 67, 3638-3642.

21. Scott, J. R.; Tremblay, P. L. Highly Reproducible Laser Beam Scanning Device for an Internal Source Laser Desorption Microprobe Fourier Transform Mass Spectrometer. Rev. Sci. Instrum. 2002, 73, 1108-1116.

22. McJunkin, T. R.; Tremblay, P. L.; Scott, J. R. Automation and Control of an Imaging Internal Laser Desorption Fourier Transform Mass Spectrometer. JALA 2002, 7, 76-83.

23. Karas, M.; Gluckmann, M.; Schafer, J. Ionization in MatrixAssisted Laser Desorption/Ionization: Singly Charged Molecular Ions are the Lucky Survivors. J. Mass Spectrom. 2000, 35, $1-12$.

24. Sprouse, S.; King, K. A.; Spellane, P. J.; Watts, R. J. Photophysical Effects Fo Metal-Carbon O Bonds in Ortho-Metalated Complexes of $\operatorname{Ir}(\mathrm{III})$ and $\mathrm{Rh}(\mathrm{III})$. J. Am. Chem. Soc. 1984, 106, 6647-6653.

25. Huheey, J. E.; Keiter, E. A.; Keiter, R. L. Inorganic Chemistry: Principles of Structure and Reactivity. Harper Collins College Publishers: New York, 1993, pp 590-591. 